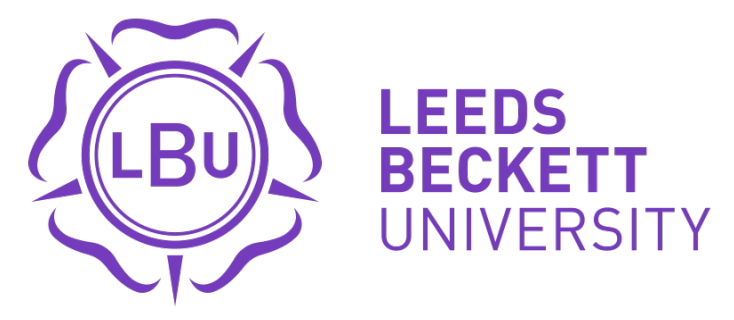

Citation:

Pham, NM and Huynh, TLD and Nasir, MA (2020) Environmental consequences of population, affluence and technological progress for European countries : A Malthusian view. Journal of Environmental Management, 260. p. 110143. ISSN 0301-4797 DOI: https://doi.org/10.1016/j.jenvman.2020.110143

Link to Leeds Beckett Repository record:

https://eprints.leedsbeckett.ac.uk/id/eprint/6535/

Document Version:

Article (Accepted Version)

The aim of the Leeds Beckett Repository is to provide open access to our research, as required by funder policies and permitted by publishers and copyright law.

The Leeds Beckett repository holds a wide range of publications, each of which has been checked for copyright and the relevant embargo period has been applied by the Research Services team.

We operate on a standard take-down policy. If you are the author or publisher of an output and you would like it removed from the repository, please contact us and we will investigate on a case-by-case basis.

Each thesis in the repository has been cleared where necessary by the author for third party copyright. If you would like a thesis to be removed from the repository or believe there is an issue with copyright, please contact us on openaccess@leedsbeckett.ac.uk and we will investigate on a case-by-case basis. 


\title{
Environmental consequences of population, affluence and technological progress for European countries: A Malthusian view
}

\author{
Nhat Minh Pham^, Toan Luu Duc Huynh', Muhammad Ali Nasir ${ }^{*+}$ \\ ${ }^{\wedge}$ Department of Social Science, University of Stavanger (Norway), n.phamminh@stud.uis.no \\ + WHU_Otto Beisheim School of Management, (Germany), toanhld@ueh.edu.vn \\ *Leeds Business School, Leeds Beckett University (United Kingdom), m.a.nasir@leedsbeckett.ac.uk
}

\begin{abstract}
This paper examines the short-run and long-run effects of economic, sociological and energy factors on environmental degradation in 28 European countries. In so doing, we employ Panel Vector Autoregressive (PVAR) and Fully Modified OLS (FMOLS) approaches on data from 1990 to 2014 in a STIRPAT (Stochastic Impacts by Regression on Population, Affluence, and Technology) framework. Key empirical results indicate that these factors may contribute to environmental improvement in the short run; however, there are adverse implications in the longrun. Specifically, economic factors including economic growth, trade openness and foreign direct investment cause environmental degradation in the under-analysis economies. The sociological factors as measured by the population growth and the level of urbanization also show a negative impact on the environmental degradation in the short-run but in the long run, both population size and urbanization increase environmental degradation. These findings are in line with the concerns raised by Thomas Robert Malthus in his Essay on the Principle of Population. With regards to the energy factors, it indicates that the renewable energies help the European environment by reducing the level of carbon dioxide emissions whereas the higher energy intensity is an ecological threat. Our results remain robust in the EKC framework.
\end{abstract}

JEL classification: F14, F15, F43, E31, Q41, Q43.

Keywords: Population; Urbanization; Pollution Heavens; Carbon Leakage, STIRPAT; economic growth; energy consumption; EKC; FMOLS; PVAR. 


\section{Introduction}

Manifested in the "2030 Agenda for Sustainable Development" issued by the United Nations (UN) (2015) as well as in the special report on "Global Warming of $1.5^{\circ} \mathrm{C}$ " (2018) by the Intergovernmental Panel on Climate Change (IPCC), sustainable development appears to be a key goal of all stakeholders of society (Paris Agreement, 2015). By the end of 2015, the UN issued 17 Sustainable Development Goals (SDGs) for the world to reach a better future by 2030. While these goals are very inclusive and cover various aspects of sustainability and sustainable development, an important aspect to account for is the role of population in sustainable development. Intuitively, there is either a direct or indirect association between some goals and demographic issues. For instance, to frame a scenario, with ceteris paribus, if population decreases, fewer households with poverty (1st goal), hunger (2nd goal) would need aids and support, and it would be easier for the world to deal with public health constraints ( $3^{\text {rd }}$ goal), illiteracy (4th goal) and gender inequality (5th goal). Undoubtedly, it is easier to imagine and said than done as population control is one of the most controversial topics in the context of sustainable development and has crucial implications for the environment and hence for the efforts to tackle the climate change.

Resource scarcity and limitation is the core of the economic and political debate. A rapid increase in population or increase in the consumption of limited resources by the existing population or a combination of both can have ecological consequences. While this issue was raised by the Thomas Robert Malthus in his Essay on the Principle of Population (1798) to a rather more recently by Kate Raworth in her Doughnut Economics, it requires some empirical evidence on the nexus between population, urbanization and other socio-economic factors with the environment to fully comprehend the impact of former. In terms of public awareness and ecological concerns, Europe and European society are very prominent and vocal. This prominence is manifested in the climate campaign started by Greta Thunberg and followed by millions of European and nonEuropean citizens and/or the mass protest in the form of extinct rebellion. Nonetheless, the themes of excessive population and its impact on the planet have also been the core debate on various media forums including movies ${ }^{1}$. This is a clear indication that environmental degradation is the core concern in $21^{\text {st }}$ century Europe and in this regard, the population is an important factor to account for. Historically, wars and epidemics have played a central role in controlling the population from the early ages to World War II. For instance, after the Black Death, Europe suffered from economic depression for a while, then to the Renaissance with recovered economy due to increase in labour wage since less workforce was available (Daily History 2019). This shall not be inferred that a disastrous is to be deserved to check the population, but it shows a fact that population plays quite a crucial role in our societies. If we look at the population dynamics in Europe, after the first Industrial Revolution, in 1900, global population was estimated to be 1.6 billion, but as the dawn of the year, 2000 broke it had reached 6.1 billion (Population Reference Bureau 2019). The Globe witnessed its citizenship quadrupling in 100 years, thanks to the rapid socio-economic progress and progress in science and technology, particularly medical science that led to increasing living standard as well as life expectancy. As the economic and technological progress did not stop, so did not the population. The world reached the threshold of 7 billion in the fall of 2011 and by the writing of this paper total world population has approximately reached 7.7

\footnotetext{
${ }^{1}$ For instnace, the story of "Inferno" film released in 2016 is about a superweapon that can eliminate half of global population created by Zobrist, who is concerned about accelerated population growth worldwide and its impact to not only the environment (IMDb 2019).
} 
billion (Worldometers 2019). With the average growth rate of $0.9 \%$ per year, by 2040 it is expected to increase to 9.1 billion (International Energy Agency: 50). Therefore, the world cannot ignore the obvious impacts of population growth in sustainable development, especially its crucial ecological influence in driving climate change.

Despite the severity of environmental problems associated with the unstainable consumption and overpopulation, the polity pays more attention to domestic economic problems than global economic issues. This is also due to the fact the domestic institutions possess only local and national level power for problem-solving (McCormick 2018). The population growth might be preferable as it may boost economic growth as measured by gross domestic product (GDP) for the national income. The economic growth and employment are undoubtedly pivotal economic indices to prove the performance of political administration to the community and society, besides the fact that these are short-term goals (McCormick 2018: 27). These political constraints act as a blindfold, preventing significant environmental policies to be put into practice. Therefore, not only the story of population and economic growth is not seen through an ecological lens, but also due to unsustainable myopic focus on growth, the burden on natural resources is multiplied exponentially, beyond the Earth's capacity. There is a limit to the Earth's capacity to provide for all its citizens that we must not cross. This concept of was mentioned centuries ago, the first with "An Essay on the Principle of Population" by Thomas Malthus in 1798 by drawing the line for survival with a pessimistic perspective towards population growth (Malthus 1798: 4,5):

"...I say, that the power of population is indefinitely greater than the power in the earth to produce subsistence for man. Population, when unchecked, increases in a geometrical ratio. Subsistence increases only in an arithmetical ratio. By that law of our nature which makes food necessary to the life of man, the effects of these two unequal powers must be kept equal."

This pessimistic viewpoint (Malthusianism) of an absolute negative relationship between population growth and the Earth's ability to provide for was shared by Garrett Hardin in "The Tragedy of the Commons" . According to Hardin, adverse socio-economic consequences will be brought by overpopulation since the common resources that are available to all social members will be excessively utilized and harm the Earth (Hardin 1968: 1244). Hardin (1968) urged on the abandonment of commons by the society including agricultural areas, cultivating lands and waste disposal places and promoted the need for an optimal threshold of the population for sustainability. Unsurprisingly, he even proposed the fertility limitation of all human beings, which has been debatable due to the ethical aspects. There might be some limitations to which these proposals can be implemented as well as the underlying theory without any room for technological advancement, the concerns raised by Hardin are cogent in terms of raising alarm on ecological grounds. Later, in their seminal work on "The Limits to Growth" by Meadows et al (1972) measured the negative impact of exponential population growth on various aspects of society and economy including agriculture to life expectancy. Three scenarios were drawn and within the boundary of finite resources, population and economy were tested with geometrical growth. Finally, two scenarios turned out to be incapable and one had an opportunity for stable development. Two decades later, in their work on "Population, Sustainability, and Earth's Carrying Capacity", Daily and Ehrlich (1992) emphasized the environmental constraints that have been putting on climate by human and tried to measure the relationship between population and "carrying capacity" of society and the

\footnotetext{
${ }^{2}$ The term The Tragedy of the Commons tracks its roots to the work by William Forster Lloyd (1833) "Two lectures on the checks to population".
} 
Earth. They acknowledged the fact that international trade can "increase global biophysical carrying capacity by lifting regional constraints and increase in efficiency". However, they cautioned that it could lead to the "Netherlands fallacy". Nonetheless, due to the international trade associated "carbon leakage", a phenomenon that the non-Kyoto countries emit more $\mathrm{CO}_{2}$ in place of the amount deficit planned and saved by Kyoto countries is also an issue (Sinn 2012). In the most recent work on the importance of sustainable consumption and being in the limits what the Earth can sustainably offer, Kate Raworth (2017) put forward the notion of "Doughnut Economics". The idea is that the human should avoid the shortfall (inner side Doughnut) to thrive and grow sustainably as well as try not to overconsume (outer side Doughnut) which could cross the planetary boundaries as Malthus identified over two centuries ago.

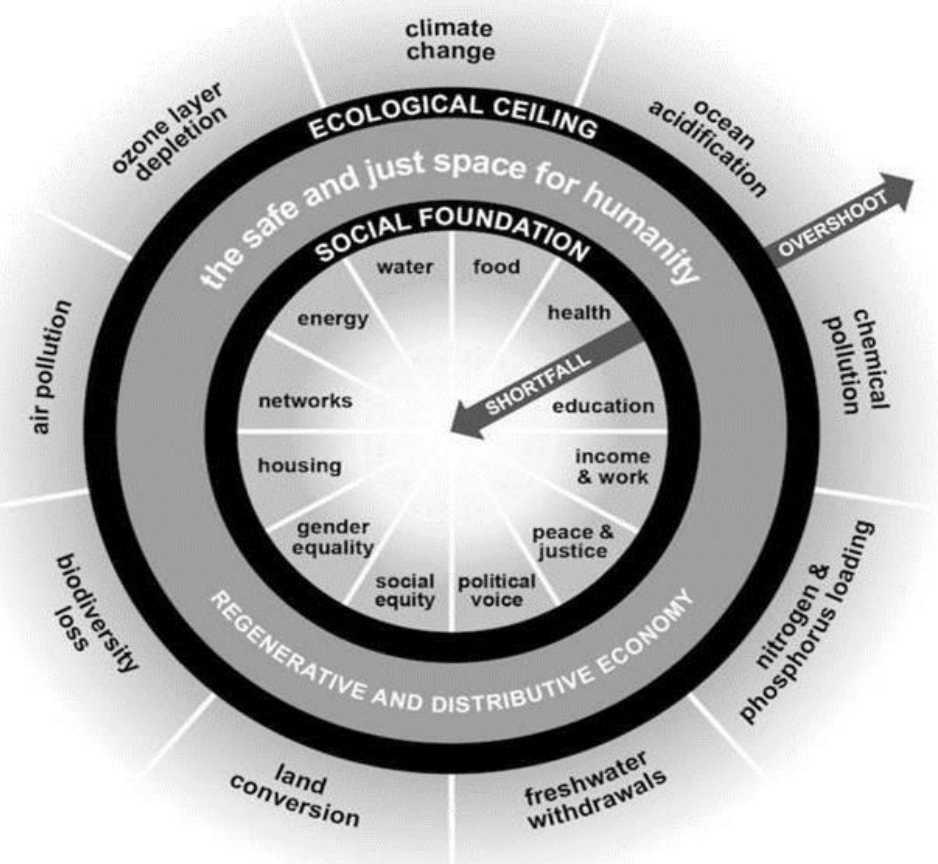

Figure 1: The Doughnut Boundaries

(Source: Raworth, K. 2017: 44)

The ideal point to be is below the "Ecological Ceiling" and above "Social Foundation" is the green comfortable sustainable part for our society to grow.

Since 2005, through the EU Emission Trading System (EU ETS), the EU has imposed taxation on carbon emission (European Commission 2015). In a first glance, it seems to work quite well when the amount of carbon emission builds up slower than before due to the rising carbon price (Markets Insider 2019) and also due to the reason that after 2020, there will be a decrease in the total fixed installation cap (European Commission 2015), however, now it has been proven to be not as efficient as it may look. Considering the fact that environmental problems possess a global effect, rising the carbon tax only within EU boundaries creates the Green Paradox (Sinn 2012). Since other developing countries imposing a lower carbon tax, corporations and firms from developed countries with a higher carbon tax are relocating their manufacturing factories to developing nations. This creates the paradox, and hence, does not turn out to have much positive effect on the

\footnotetext{
${ }^{3}$ Notion that the ecological impact of Netherland (or other countries) is contained to their national borders (Ehrlich and Holdren 1971).
} 
total amount of global emission. Environmental issues need an intergovernmental regime to solve them, and yet we do not have the consensus needed. With the tighter co-operation between leading countries can have somehow help to curb CO2 emission (McCormick 2018). In specific to Europe, it is important to acknowledge that the EU has been continuously reiterating its commitments to tackle climate change. While not only that all the member countries have the signatory of the Paris Agreement, Europeans have played a crucial role in brokering the Paris Agreement. Under the 2030 climate \& energy framework, the EU has set the nationally determined contributions. Specifically, it seeks to reduce greenhouse gas emissions by a minimum of $40 \%$ by the year 2030 as compared to the 1990 s levels. The necessary legislation has already been complicated ${ }^{4}$.

The linkages between population, economy and environment sound logical. Through various channels and pathways, changes in population size, for instance, by adjustment of fertility, mortality, and demographic dividend, together with non-working ages and net immigration can cause huge impacts on economic growth and also put stress on the environment. The world population is consistently increasing and without control, the Anthropocene would lead to the $6^{\text {th }}$ extinction (Kolbert 2014), and then finally the fate of human lead to extinction (Pimm, et al. 2014). In contrast, until now, there have not been serious efforts to control the population and even China has recently abandoned the one-child regime (Westcott 2018). Similarly, in Norway, Prime Minister- Mrs Erna Solberg has expressed worrying thought about low fertility rates and urge Norwegians to bear more babies (Taylor 2019). This debate and persuasion raise ecological questions. Most importantly, what are the ecological implications of population growth, particularly in European countries? Given the fact there are related aspects of urbanization, economic and financial activity, investment and trade which are fundamental to the contemporary society, it also raises the question that what implications these factors could have for the environment?

The population-environment nexus is scrutinized in the context of developing and populous countries, for instance, China, India or African countries. On the other hand, developed countries with high life quality and low population growth rate, such as the European countries, are usually neglected. The reason that Europe includes some of the most affluent countries with low population growth rate shall not imply that we ignore the ecological implications of population, urbanization and economic activity. On this aspect, Martínez-Zarzoso et al (2007) did employ a STIRPAT model on some of the European countries by focusing on the pre-European Monetary union period (1975 to 1999). Their STIRPAT model including only four variables i.e. population size, GDP, industrial activities and energy intensity and the results did not yield as significant results as the subject study. The main focus of their analysis was the comparison between old and new EU member states and comparison of elasticity of population size with respect to environmental deterioration. However, in this study, we are taking a more inclusive approach by including more factors, novel empirical approaches, a dataset which corresponds to Post EMU period, and both STIRPAT and EKC frameworks. Concomitantly, in the context of the debate on the role of population growth, urbanization and economic activity for the environment, we aimed to empirically analyse the relationship of these factor with environmental degradation in European countries. Drawing on the theoretical foundation laid by Paul Ehrlich (1971) in his argument that the nexus between population affluence, technology and the anthropocentric impact (I) on environment can be measured by the magnitude of population growth (P), affluence growth (A), and technological advancement (T), IPAT model is chosen has analytical framework. Extending the primary model,

${ }^{4} 2030$ climate \& energy framework see more in https://ec.europa.eu/clima/policies/strategies/2030_en 
it can be connected and applied it into the regime of industrial ecology, which leads to transformation into the Stochastic Impacts by Regression on Population, Affluence, and Technology (STIRPAT) model. The existing literature on the STIRPAT has shown that at least on some occasion's population correlates with environmental degradation. In the parallel strand of literature, some studies have applied the Environmental Kuznets Curve (EKC) and came up with similar results featuring a U-shaped quadratic relationship. However, while EKC seems to rely on the advancement of technology and political regulations that curb future emission which may result in less environmental degradation, a number of studies keep a negative perspective on the EKC (Shahbaz and Sinha, 2019) which makes the STIRPAT an alternative analytical framework. Keeping these aspects of both frameworks, we have mainly focused on the STIRPAT, however, also applied the EKC framework for robustness. Drawing on the 25 years data on 28 European countries (1990 to 2014) collected from World Development Indicator, we run the PVAR (Panel Vector Autoregressive) for short-run estimation and the FMOLS (Fully Modified OLS) for longrun evaluation of the association between under analysis variables. Our key empirical results indicate that these factors have contributed to environmental improvement in the short run; however, there are adverse implications in the long-run. Specifically, economic factors including economic growth, trade openness and FDI causes environmental degradation in the under-analysis economies. The sociological factors as measured by the population size and the level of urbanization also showed a negative impact on the environmental degradation in the short-run but in the long run, both population growth and urbanization increased environmental degradation. These findings are in line with the concerns raised by Thomas Robert Malthus in his Essay on the Principle of Population. With regards to the energy factors, it indicates that the renewables help the European environment by reducing the level of carbon dioxide emissions whereas the higher energy intensity is an ecological threat. The empirical results are found to be strongly robust since all of the variables have long-run impact on carbon emission with at a statistical significance level of $1 \%$ and 5\%, in STIRPAT and EKC frameworks. This leads to various policy implications regarding factors and their role in European achieving their environmental goals and honouring commitments to the Paris Agreement.

The paper proceeds as follows: Section 2 critically discuss the existing evidence on the subject in the light of Malthusianism and Cornucopianism as well as sheds light on the IPAT framework. Section 3 explanation of the theory we choose and the formation of the STIRPAT model with its variables. Section 4 presents empirical results and discussion and section 5 entails conclusion and policy implications.

\section{Literature Review}

\subsection{Population and Environment}

Population dynamics are at the core of the debate on environmental degradation. Since, pioneer contribution the Malthus (1798), there are several studies which have supported scepticism of Malthusianism. Most prominent among them is Ehrlich (1968) with his book "The Population Bomb" which gained a great amount of attention and sparked debate on nexus between demography and environmental degradation. Ehrlich (1968) discussed the notion of moving the population to other planets, since "the extremely remote possibility of expanding into outer space offers no escape from the laws of population growth". Later, Odum and Odum (2001) in "A Prosperous Way Down", stated that nature has the cycle of "succession" and "decession", or growth and degrowth. They described that how in our lives we witness the pulsing cycle of nature with four main stages, from the beginning growth due to huge pool of resources to the second phase 
of expansion until the turning point. When there is not enough energy and resources, growth will start to decrease as the third to the last stage of poor-energy restoration (Odum and Odum 2006). Though nature always follows the rule of the universe, human beings are trying to play the game with their own rules.

Despite the concerns raised by various scholars, world population has been continuously increasing, particularly in the developing countries, putting more stress on the capacity of the ecosystem. The sustainable solution shall, therefore, account for the population control, with the main idea that population shall increase at the same rate as the rate of sustainable resource exploration. Since population growth momentum may overshoot, for sustainable development it may require decreasing the rate of population growth. Among the contemporary vocals, Raworth is one of the most prominent scholars how has emphasised on the sustainable consumption in her seminal work "Doughnut Economics". Raworth (2017) did give some solutions based on a less sceptical viewpoint. It was argued that the problem does not lie only in population or economic growth, but it is also about how sustainably utilise the resources and go beyond the myopic objective of economic growth often measured in terms of GDP. Furthermore, the faster we can decouple the resources from growth, the safer our future will be. The empirical studies on the nexus between population and environmental degradation also support the notion negative impact on the environment. For instance, using cross-sectional data from 86 countries, Jorgenson and Clark (2010) analysed the impact of population carbon emission. Their results showed that regardless of the economic growth of a country, the population still correlates strongly and positively with CO2 emission. Similarly, in a study on OECD countries, Menz and Welsch (2012) reported a positive correlation between population factors and environmental degradation.

\subsection{Economic Growth and Environment}

Population dynamics are important for economic activity which is the outcome of human civilisation and hence there is indispensable leverage of population to the economy and vice versa. For this reason, a number of studies have urged that economic factors should not be ignored when investigating the nexus between population and societal sustainability (Liu and $\mathrm{Hu} 2013$; Peterson 2017; Wongboonsin and Phiromswad 2017; Golley and Wei 2015; Bucci, Eraydin and Muller 2018). As Chinese experience clearly shows, the working-age population (demographic dividend) possesses a positive influence on economic growth due to increased physical production (Liu and $\mathrm{Hu}$ 2013). However, the increase in the fertility rates may impact growth negatively due to the resulting increase in non-working demographic share and decrease of "population dividend or working-age proportion (Cai 2010). Of course, the mechanisation and sectoral changes from agricultural to more industrial economy also play an important part in the nexus between population and economic growth (Golley and Wei 2015). Despite the positive relationship reported by a number of studies, there is a strand of literature, which rejects this notion. For instance, Peterson (2017) and Wongboonsin and Phiromswad (2017) differentiating between high and low-income countries argued that the low population growth negatively affects the society in developing countries due to the rise of poverty and decrease in demographic dividend; and vice versa in the case of developed countries, particularly when they face a huge increase in pensioners with old population scheme. For these reasons, in a recent study, Bucci et al. (2018) argued that there is a thin blue line between population and economic growth nexus, which could depict either positive or negative relationship. Analogous to the fact that the connection of population and economic activity is crucial, nexus between population and environmental degradation is also undeniably important as the economic growth influence the ecosystem. A number of studies on developing 
and developed countries has shown that the $\mathrm{CO} 2$ emission is mainly contributed not because of population growth but economic expansion (see e.g. Liddle 2011, 2013; Bargaoui et al 2014; Dong et al 2018; O’Neill et al. 2012).

The issue of growth and de-growth has been on the most controversial discourses. Growth measured in terms of GDP does not fully encompass the human development and progress (Raworth 2017). Therefore, a new line of thinking is required to emerge which does not end the existence of GDP, yet it can decouple resources from growth. Growth itself does not contain much toxic influence, yet the engine for economic growth consumes too much of the resources that the Earth can provide. As some estimates suggest, if everybody in the world lives like the French, we will need 2.5 times the resources Earth can provide and if everybody needs consumption equal to an American citizen, we will require 4 times more resources than Earths can provide (Per Square Mile 2012). Thus, there is an imperative demand to have the right pathway for growth. In her book, Kate Raworth has projected some scenarios with different percentage of resource decoupling, and the more we can decouple, the faster we can save our Earth (Raworth 2017). One of the pivotal solutions to achieve this decoupling future is through a circular economy. Various studies have tried to define what the circular economy is (Kirchherr et al 2017), yet there is one common view that the economy needs to reuse, recycle, and reduce the raw resources for production and consumption (Kalmykovaa et al 2018). They separated two loops, one is the biosphere and the other is the Technosphere (McDonough and Braungart 2002). A product should be viewed in a combination of these two spheres, which the bio-parts should be produced to have the possibility of recycling in nature states, and the techno-parts should be produced to reuse as much as possible. Although there are still many barriers for the circular economy, such as its own rebound effect and the obstacles in imposing regulations, the EU now is integrating this wonderful concept into its development goal (European Commission 2019).

\subsection{Energy Intensity and Environment}

Technological factors that lead to increased energy efficiency stands out in terms of their ability to influence the nexus between population, economic activity and environmental degradation. Unlike population and affluence, technology improvements through progress in energy efficiency tend to have a negative impact on environmental degradation. This can be explained as technological advancement from the First Industrial Revolution (coal resources and steam power) to the Fourth Industrial Revolution (artificial intelligence for efficient resource utilisation) have a core goal to increase the energy efficiency, so that industrial progress can continue (Rifkin 2011). While the usage of fossil fuel and non-renewable resources have adverse consequences for the environment, renewable energy and technological advancements are positive factors. Thanks to the green transition, renewable energy and improvements in energy efficiency due to technological progress can be seen as compensating factors for population and economic activity. Figure 2 expresses the expected correlations of the three factors on environmental deterioration. However, this cannot be interpreted that population and economic growth can increase ceaselessly as argued by the Cornucopianism, a school of thought contrarious to Malthusianism, Cornucopianism claims that the world is full of new potentialities, and more human beings meaning that there are more grey matter and more geniuses will solve the problems the world will be facing (Jonsson 2014). Furthermore, the "diminishing returns and scarcity are constantly felt forces, but their economic consequences have been creative rather than catastrophic. Scarcity triggers expansion, innovation, and substitution instead of misery feared by Malthus. Hence, the resources should be defined "in terms of known technology" rather than "absolute limits." (Jonsson 2014). Nevertheless, as these claims about the future, which is unknown. 
Therefore, to gain better control of resources and growth, one shall be sceptical, as scenarios projected often do not turn out to be as expected.

Technological progress has been continuously re-framing the picture of economic, social and environmental change. During the First and Second Industrial Revolution, it was seen as a crucial tool for economic growth, yet the idea of "dirty" growth became popular in the age of third Industrial Revolution with public support for shifting concentration of the energy mix from fossil fuel sources to renewable energy. According to Dong et al. (2018), renewable energy intensity creates an affirmative impact on carbon emissions. While technology plays an important role in dealing with socio-economic problems in developing countries, it also partly alleviates the carbon emission. Technology also has a great impact on the population, reshuffling the demographic structure from high birth - high death rate to low birth - low death rate. This led Ausubel and Langford (1997) to argue that if population and affluence are the push factors for carbon emission, then technology can be the pull factor. In a study by Grether et al (2009) which focused on sulfur dioxide $\left(\mathrm{SO}_{2}\right)$, it was reported that the technique effects have led to a significant reduction in emissions. It is worth noting that the study by Tsurumi and Managi (2010) showed that while technique effect was affective in reducing sulfur dioxide emissions, it did not help much in reducing the carbon dioxide (CO2) emissions and energy consumption, except some of the developed countries. Furthermore, the recent study by Hille and Shahbaz (2019) showed that the technique effects depends on the market and environmental policy stringency. These arguments and findings by Tsurumi and Managi (2010) and Hille and Shahbaz (2019) raise the question that whether in the case of subject European countries, the technical progress has played any role.

\subsection{STIRPAT \& EKC Frameworks}

Population, economic growth and technology and strongly interrelated by their association with the environment is also very crucial for climate change. In order to comprehend the negative impact of population on environment a number of studies have applied the Stochastic Impacts by Regression on Population, Affluence, and Technology (STIRPAT) framework (see, for instance, O’Neill, et al. 2012, Yeh and Liao 2017; Liddle 2011, 2013; Bargaoui et al 2014; Dong et al. 2018) whereas, others (e.g. Hanif et al 2017; Wang et al 2015; Zhang et al 2018) have argued that the population influences environment in a U-shaped curve, called the Environmental Kuznets Curve (EKC). However, for the three factors i.e. population, economic growth and environment Stochastic Impacts by Regression on Population, Affluence, and Technology model (STIRPAT) is the most common framework. In this regard, Erhlich and Holdren (1971) made the seminal contribution in measuring the impact on the local and global ecological surroundings. They concluded that "Precisely because the population is the most difficult and slowest to yield among the components of environmental deterioration, we must start on it at once" (1971: 1216). We start with the following specification:

$$
\begin{aligned}
& I=P X F \\
& I=P X F(P)
\end{aligned}
$$

Where $I$ denotes the impact on the environment, $\mathrm{P}$ is population and $\mathrm{F}$ stands for other factors that are influenced by population change. To land with the IPAT equation, the primary (2) equation by Ehrlich was put in controversial academic discourses, first to find a way to measure the impact 
more precisely, and second to find a consensus in the scientific world (Chertow 2001). The discourse was known as the Simon - Ehrlich wager ${ }^{5}$. Because of intense debate, Ehrlich and Holdren transformed the discourses between the dependent variable I (impact, mostly by pollution at that time) and 3 other independent variables: $\mathrm{P}$ (population), A (affluence) and T (technology) to equation (3) and (4):

$$
\begin{gathered}
\text { pollution }=\text { population } \times \frac{\text { production }}{\text { capita }} \times \frac{\text { pollution emission }}{\text { production }} \text { (Eq. 3) } \\
I=P \times A \times T
\end{gathered}
$$

Therefore, affluence is usually measured by GDP per capita, and technology is seen with the aspect of energy intensity and energy efficiency of a nation. However, this equation has difficulties in hypothesis testing of cross-sectional and longitudinal data since it merely expresses to an extent the qualitative side of the problem, not for data application (Liddle 2011). Moreover, since Affluence and Technology are seen as intercorrelated with the population that proportionality between factors was embedded inside the equation. The study by Dietz and Rosa (1997) was the first to apply the stochastic version of IPAT i.e. STIRPAT. This transforms the equation (4) to:

$$
I_{i t}=a \cdot P_{i t}^{b} \cdot A_{i t}^{c} \cdot T_{i t}^{d} \cdot e_{i t}
$$

The subscript "i" is used for observational data, " $t$ " for time, " $a$ " is the intercept and " $b$ ", "cc" and "d" are seen as elasticities of each variable to environmental impact. The parameters need to be estimated, and "e" is the error term. When applying the natural logarithms to equation (5) can be specified as follows:

$$
\begin{gathered}
\ln I_{i t}=\alpha_{0}+b \cdot \ln P_{i t}+c \cdot \ln A_{i t}+d \cdot \ln T_{i t}+\mu_{i t} \\
\text { with } \ln a=\alpha_{0} \text { and } \ln e_{i t}=\mu_{i t} .
\end{gathered}
$$

There are a number of studies, which applied this framework to analyse the impact on the environment. For instance, in the case of Taiwan, Yeh and Liao (2017) reported that population growth correlates positively with $\mathrm{CO}_{2}$ emission, while economic growth showed negative impact. Although the stud focused on population and economic activity, yet it did not include the factor $\mathrm{T}$ - technology. In another study by Liddle (2011) on OECD countries, STIRPAT was applied with separation of age structures and to analyse the association between two main $\mathrm{CO}_{2}$ emission sectors i.e. transport and household. The results showed different coefficients for transport and household emissions. A later study by Liddle (2013) employed a panel cointegration approach to investigate the $\mathrm{CO}_{2}$ emissions of the rich, middle and poor countries from the pool of 31 developed OECD countries and 54 developing non-OECD countries. The results showed that the urban population and income growth positively affect carbon emissions. However, the intensity of correlation varies between developed and developing countries. In a study by Bargaoui et al (2014) which applied STIRPAT framework it was concluded that both demography and economic development have a negative impact on the environmental quality. Furthermore, that the industrial activities play the main role in increasing carbon emission while urbanization seems to have varying impact on carbon emission, which positively correlated with environmental degradation, but then there was a decrease in the magnitude of impact. A recent study by Dong et al (2018) argued that while the other factors do matter, technology factor or renewable energy intensity relieves the intensity of

5 Julian L. Simon (economist) and Paul Ehrlich (biologist) madea bet about the rise of prices from 1980 to 1990 of 5 vital raw materials i.e. chrome, copper, nickel, tin, and tungsten (see Kiel et al 2010 for details). 
carbon emissions. Thus, it provides support to the fact that green energy sources will be one of the utmost important factors for dealing with climate change. Furthermore, regardless of the level of income in different nations, urbanization still correlates positively with carbon emission (Poumanyvong and Kaneko 2010). Other studies also showed the positive association between population and economic growth to environmental degradation indices (Dong, et al. 2018; O’Neill, et al. 2012; York et al 2003). Noticeably, according to York, et al (2002), the three factors possess different magnitude in alleviating environmental degradation by distinctive ways, thus there is a balanced importance of these three factors.

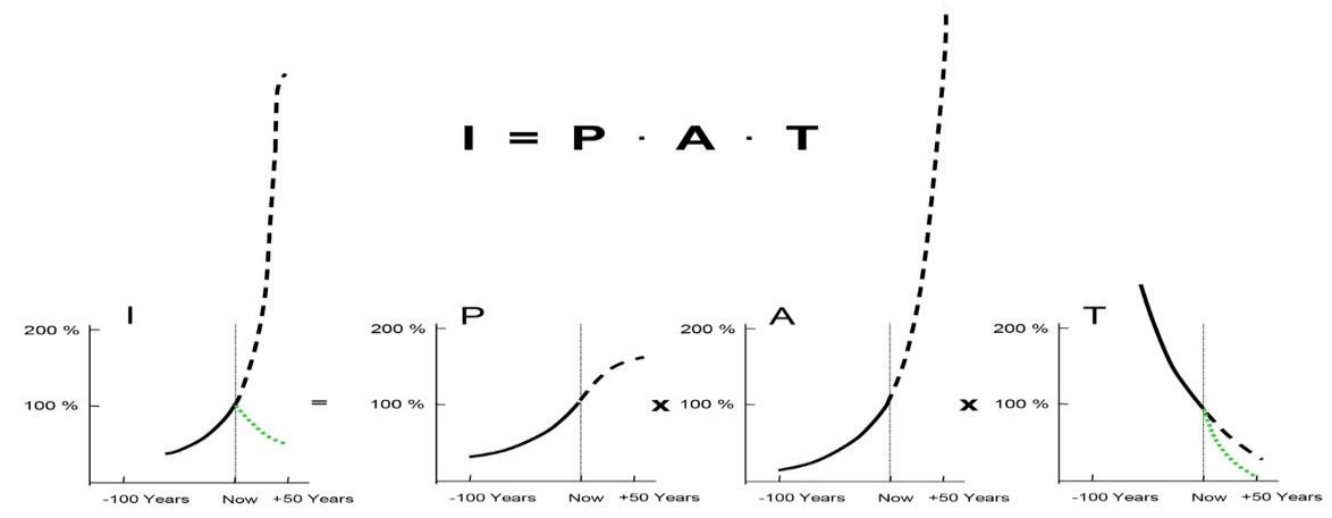

Figure 2: The relationship of population, affluence, and technology on carbon emission. Source: Wenzel (2019).

Besides STIRPAT, there are a number of studies which used the EKC framework to investigate the interaction between population and the environment. The notion of EKC was put forward by Grossman and Krueger (1991) while investigating the correlation of air pollutants and economic growth by the North American Free Trade Agreement (NAFTA). They found that air pollution was alleviated by the economic growth until a country's per capita income reached a threshold of $4000 \$-5000 \$$, thereafter its pollution levels decreased. Since then several studies have applied the EKC framework to analyse the effects of population and economic growth on the environment. For instance, on China, Zhang et al. (2018) reported that GDP per capita and CO2 emission have is an inverted U-shape relationship. In this context, Wang et al. (2015) argued that the population accelerates the escalation and diminishment of the process, making two slopes on two sides of the curve steeper (Wang et al. 2015). In a study focusing on developing countries, Hanif et al. (2017) confirmed the EKC relationship between environmental degradation and economic growth, and population plays an important role (Hanif et al 2017). However, an important aspect we need to not lose sight of is that the $\mathrm{CO} 2$ emission is a global issue and its consequences are international with long-term future impact. Although some countries are decreasing their emission while others increasing which implies that sources of emissions move from one country to the other i.e. "carbon leakage" phenomenon (Sinn 2012). However, EKC studies claim that the rise and fall of environmental degradation is easy to be captured and understood, and degradation does not continue perpetually. In contrast, carbon emission relates directly to fossil fuel and the green policies are difficult to control and predict (van der Ploeg and Withagen 2015). According to the EKC framework, at some measurable turning points of income growth or GDP growth that carbon emission has a declining tendency. Furthermore, EKC is seen as a hypothesis and the researchers can add as many different variables as they wish to the equation with one quadratic variable to form the nonlinear regression and finally gain a result of the inverted 
U-shaped curve. In fact, the EKC has some serious limitations as the turning point occurred by accidental reasons from the Great Acceleration Era of America only, and it only contains "5 per cent empirical information and 95 per cent speculation, some of it possibly tainted by wishful thinking". On the contrary, STIRPAT requires scrutinizing three main factors including population, affluence and technology that together, put an overall impact on the environment. Hence, STIRPAT is more than a hypothesis; it is a framework with a pre-designed model to verify the exact reality that one might be observing. Therefore, Liddle (2013) argued that that it seems that EKC is not a wise choice for measuring the impact of environmental degradation, especially carbon emission. There is also a strand of literature, which looked at the environmental degradation, beyond by not focusing on these two models (Chang et al. 2018; Marsiglio 2011; Rodriguez-Gonzalez et al. 2018; Siche et al, 2008). A study by Marsiglio (2011) controlled the other variables to focus on the effects of fertility choices on natural resources. It was argued that even in the best-case scenario of unlimited natural resources, sustainability cannot be guaranteed. Rodriguez-Gonzalez et al. (2018) constructing a complicated model which entailed human as well as flora and fauna as a centre of the worldwide ecosystem, embedded with macroeconomics perspectives the results suggested that sustainability will be more biased with developed than developing countries. This implies that the developed countries and regions such as Europe, despite all the socio-economic development can be complacent in the existing state of affair and look rather towards the developing countries, though its own levels of population and affluence might be causes more ecological degradation.

\subsection{Methodology}

STIRPAT framework describes the environmental impact of three sectors: (i) population, (ii) affluence, and (iii) technology (Chertow 2001). These three elements coherent with each other to influence the global ecosystem. The $\mathrm{CO} 2$ emissions i.e. environmental degradation is caused by the three independent elements. The carbon dioxide is seen as the main effect of Anthropocene to global warming and climate change (O’Neill, et al. 2012). Some other air pollutants are not chosen due to the scope of this study, although to some extent they cause harms to the environment. The carbon emission with its rise reported yearly by the International Energy Agency is a great concern of the scientific studies, (IEA 2017, 2018:). There are some existing studies which have also concentrated on CO2 emission while applying STIRPAT (Dietz and Rosa 1997; Dong, et al. 2018; Liddle 2011, 2013; O’Neill, et al. 2012; Bargaoui et al 2014; Yeh and Liao 2017).

With regards to the population, there are many internal factors that can be analysed by STIRPAT. Some studies use the population size (Dietz and Rosa 1997; Bargaoui et al 2014; Dong, et al. 2018; Liddle 2015; Jorgenson and Clark 2010; Martinez-Zarzoso et al 2007) while others use total urban population (Liddle 2013) and urbanization (York et al 2003; Poumanyvong and Kaneko 2010; Martinez-Zarzoso and Maruotti 2011) or demographic dividend with different age limit ranges to depict the population transition of the pool samples (Yeh and Liao 2017; Liddle 2011; Menz and Welsch 2012; Liddle and Lung 2010), or the combination of several above measures (O'Neill, et al. 2012; Cole and Neumayor 2004). In this study, we are taking a more inclusive approach to papulation factor to increase the reliability of our estimates (Neuman 2014). Therefore, the population factor will be constructed by incorporating population size as well as the urbanization rate. The reason for choosing population size is to know whether changes in population size, which indirectly implies changes in fertility rate and mortality and ageing percentage correlate with carbon emissions. Whereas the Urbanization has been continuously increasing the European nations, which gradually intensifying the degree of carbon emission. 
To measure the affluence, most of the studies so far considered the GDP per capita. However, it has also been argued since the industrial activity emits carbon dioxide, the share of industries (Poumanyvong and Kaneko 2010) or industrial activity (Bargaoui et al 2014; Liddle 2015; Martinez-Zarzoso et al 2007) can also be seen has variables to focus on. Contextualising on these arguments and degree of globalisation, in this study we employ three measures to account for the affluence and economic activity, including GDP per capita, Trade and Foreign Direct Investment (FDI). The increasing international expansion and growth associated with globalisation imply the global spread of industrialisation usually to developing countries outside Europe. With this kind of outsourcing, industrial activities within European countries still cannot cover all the carbon emission which should have been emanated inside Europe. Therefore, Trade and FDI are the important factors variables to account this leaking effect.

Lastly, the technology progress which an indispensable factor in terms of its importance for the environment as well as our analytical framework. This factor has been measured in various manners (Wei, T. 2011). Some did not explicitly account for technology, due to the reason that it can be denoted as other factors that can affect the equation i.e. error term (Dietz and Rosa 1997). Other studies used aggregate energy intensity (Poumanyvong and Kaneko 2010), energy efficiency (Bargaoui et al 2014), renewable energy intensity (Dong, et al. 2018), residential energy consumption (Liddle 2013) or the share of industrial activity (Shi 2003; Yeh and Liao 2017; York et al 2003; Martinez-Zarzoso, et al 2007) or the combination of these variables (Cole and Neumayor 2004; Martinez-Zarzoso and Maruotti 2011, Liddle and Lung 2010; Liddle 2015). Therefore, the differences in the results originated from the variety of unit of analysis and perspectives of these studies (York et al 2003). The subject study takes an inclusive approach and considers a) energy intensity because it will provide embedded information about how energy consumption in the functioning of economy $b$ ) renewable energy consumption since non-fossil fuel energy resources important technological improvements in terms of the environment. Concomitantly our STIRPAT model can be specified as follows:

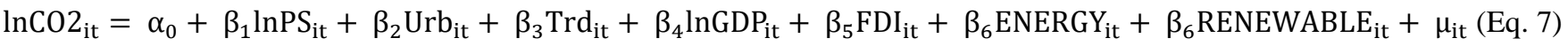

Where $\mathrm{CO}_{2}$ is carbon emissions per capita, $\mathrm{PS}$ is population size. Urb is urbanisation rate, Trd is Trade as ratio (\%) of GDP, GDP is GDP per capita, FDI is Foreign Direct Investment ratio of GDP (\%), EI refers to Energy Intensity as ratio of GDP (\%) and REC is Renewable Energy Consumption as ratio of final energy consumption (\%). Due to our application to STIRPAT model, we take the natural logarithm for variables, which are in absolute values in order to make them consistent to the theoretical framework. In terms of estimation strategy, at first, we will employ the crosssectional dependence test to examine whether cross-sectional dependence exists in our dataset. The approach proposed by Pesaran $(2004,2007)$ is followed to observe if each variable has a different impact through the stochastics residual part for Augmented Dickey-Fuller test.

$$
\varepsilon_{\mathrm{it}}=\theta_{\mathrm{i}} \mathrm{f}_{\mathrm{t}}+\mathrm{u}_{\mathrm{it}}
$$

Here $\theta_{i}$ denotes the differences in terms of individual impact while $u_{i t}$ considers as no crosssectional dependence and no autocorrelation. This study attempts to integrate the CIPS (Crosssectional IPS) which is developed based on the seminal work by Im Pesaran-Shin (2003). This novel approach supplements the cross-sectional ADF (called by CADF) and o control the cross- 
sectional dependence in case this phenomenon happens. Furthermore, in order to ensure that our dataset has panel co-integration we follow the approach by Kao (1999) and Pedroni $(1999,2004)$ which can be specified in the following form:

$$
y_{i t}=x_{i t}^{\prime} \beta_{i}+z_{i t}^{\prime} \gamma_{i}+e_{i t}(\text { Eq. 9) }
$$

In which, $\beta_{i}$ represents the co-integrating vector which might have different characteristics across panels. $\gamma_{\mathrm{i}}$ is a vector with estimated coefficients on $\mathrm{Z}_{\text {it }}$ to control panel-specific effects and linear time trend. The $\mathrm{e}_{\mathrm{it}} \sim N\left(0 ; \sigma^{2}\right)$ is white noise. Therefore, the co-integration determines whether the long-run effects exist or not. Finally, our paper employs FMOLS (Fully Modified OLS) and PVAR (Panel Vector Autoregressive) to estimate the long and short-time impact ${ }^{6}$.

\subsection{Data}

In order to ensure the consistency and reliability of dataset, we collected the balanced panel data from the World Bank's World Development Indicators for 25 years for the European countries. Specifically, our dataset covers for 28 economies $^{7}$ in the European region with the time period from 1990 to 2014 (the ending year of World bank data announcement). The choice of time horizon is based on the availability of data for 28 countries and therefore, in order to have a balanced panel, we have to consider this time horizon.

Table 1. Summary of Variables

\begin{tabular}{|c|c|c|c|}
\hline Indicator & Variables & Explanation & Sources \\
\hline $\begin{array}{l}\text { The impact on } \\
\text { carbon emission }\end{array}$ & $\mathrm{CO}_{2}$ & $\begin{array}{l}\mathrm{CO} 2 \text { emissions (metric tons per } \\
\text { capita, taking into natural } \\
\text { logarithm form) }\end{array}$ & \\
\hline $\begin{array}{lr}\text { Capital } & \text { flows } \\
\text { through } & \text { the } \\
\text { investment } & \\
\text { activities } & \end{array}$ & FDI & $\begin{array}{l}\text { Foreign direct investment, net } \\
\text { inflows ( } \% \text { of GDP). }\end{array}$ & \\
\hline $\begin{array}{l}\text { The level of using } \\
\text { energy }\end{array}$ & ENERGY & $\begin{array}{l}\text { Energy intensity level of } \\
\text { primary energy (MJ/\$2011 PPP } \\
\text { GDP). }\end{array}$ & World Development \\
\hline $\begin{array}{l}\text { The level of using } \\
\text { alternative and } \\
\text { sustainable energy }\end{array}$ & RENEWABLE & $\begin{array}{l}\text { Renewable energy } \\
\text { consumption ( } \% \text { of total final } \\
\text { energy consumption). }\end{array}$ & \\
\hline $\begin{array}{l}\text { Capital flows } \\
\text { through the } \\
\text { trading activities }\end{array}$ & TRADE & $\begin{array}{l}\text { The sum of exports and imports } \\
\text { of goods and services measured } \\
\text { as a share of gross domestic } \\
\text { product ( } \% \text { over GDP). }\end{array}$ & \\
\hline Economic growth & GDP & $\begin{array}{l}\text { GDP per capita (taking into } \\
\text { natural logarithm form). }\end{array}$ & \\
\hline
\end{tabular}


Total population is based on the

Population size

POPULATION

de facto definition of

population (taking into natural

logarithm form).

The level of urbanization
URBAN
Urban population (\% of total population).

In order to obtain the consistent and robustness results, we obtain all dataset from World Development Indicator to achieve well-matched data.

Before going to inferential quantitative analysis, we would present the summary of descriptive statistics. By doing this, we can overview of data structure and its characteristics.

Table 2. Descriptive statistics

\begin{tabular}{cccccc}
\hline Variable & Mean & Std. Dev. & Skewness & Kurtosis & JB \\
\hline $\operatorname{lnCO} 2$ & 2.0141 & 0.3967 & 0.3662 & 3.5044 & $23.07 * * *$ \\
FDI & 8.2049 & 30.5976 & 10.0372 & 121.0429 & $420000 * * *$ \\
ENERGY & 5.6611 & 2.3987 & 1.6993 & 6.6682 & $729.4 * * *$ \\
RENEWABLE & 0.1281 & 0.1108 & 0.9950 & 3.1039 & $115.8 * * *$ \\
TRADE & 1.0155 & 0.5663 & 1.8737 & 7.4534 & $988.1 * * *$ \\
lnGDPpercapita & 9.6563 & 0.9745 & -0.6561 & 2.7784 & $51.66^{* * *}$ \\
lnPOPULATION & 15.8585 & 1.4030 & -0.2471 & 2.5735 & $12.43 * * *$ \\
URBAN & 0.7107 & 0.1213 & 0.1986 & 2.3226 & $17.99 * * *$ \\
\hline *** p<0.01, ** $<<0.05, * \mathrm{p}<0.1$. The null hypothesis of Jarque-Bera test is that the distribution of variables follows normality. This table \\
summarizes the mean value, standard deviation, skewness and kurtosis of our research variables.
\end{tabular}

Table 2 shows that all the variables have non-normal distribution as the Jarque-Bera test's results rejected the null hypothesis of normal distribution. We also performed the Pesaran's test of crosssectional independence. The results indicate the strength and existence of cross-sectional dependency. The null hypothesis proposed by these tests is no cross-sectional dependency. However, the chi2-value ( $\chi^{2}$ value: 5.498, significance level at $1 \%$ ) demonstrates that we must reject the null hypothesis. Hence, the following quantitative techniques will account for the crosssectional dependence among variables.

\section{Analysis \& Findings \\ 4.1. Stationary test}

Considering the fact that the initial test indicated cross-sectional dependence among variables, therefore, we employ the Im-Pesaran-Shin (2003) test for stationary which accounts for the presence of cross-section dependence. This test is mainly based on the strict assumption of unit root test theorem; therefore, our results will avoid the spurious estimations.

Table 3. Pesaran Unit root test

\begin{tabular}{|c|c|c|}
\hline Variables & T-statistics & Conclusion \\
\hline $\operatorname{lnCO}{ }_{2}$ & -1.0234 & Non-stationary \\
\hline FDI & $-3.1693 * * *$ & Stationary \\
\hline
\end{tabular}




\begin{tabular}{lcc} 
ENERGY & -0.6348 & Non-stationary \\
RENEWABLE & 0.7744 & Non-stationary \\
TRADE & -0.9200 & Non-stationary \\
lnGDPpercapita & -0.6518 & Non-stationary \\
lnPOPULATION & 0.2252 & Non-stationary \\
URBAN & -0.0054 & Non-stationary \\
\hline $\begin{array}{l}\text { The symbols } *, * *, \text { and } * * * \text { denote the significance at the 10\%, 5\%, and 1\% levels, respectively. The Im-Pesaran-Shin unit-root } \\
\text { test, } H_{0}: \text { Panels contain unit roots and } H_{A}: \text { Panels are stationary. }\end{array}$
\end{tabular}

As the results in Table 3 show, only FDI is stationary at $1 \%$ significance level. The remaining variables are non-stationary at the level. Hence, is important to test whether these variables are first-difference. Table 4 represents the Im-Pesaran-Shin (2003) test for the first differences of these variables.

Table 4: Pesaran Unit root test at first-difference

\begin{tabular}{|c|c|c|}
\hline Variables & T-statistics & Conclusion \\
\hline D. $\operatorname{lnCO} 2$ & $-5.7490 * * *$ & $\begin{array}{l}\text { Stationary at } 1 \% \\
\text { significance level }\end{array}$ \\
\hline D.ENERGY & $-5.6924 * * *$ & $\begin{array}{l}\text { Stationary at } 1 \% \\
\text { significance level }\end{array}$ \\
\hline D.RENEWABLE & $-5.0787 * * *$ & $\begin{array}{l}\text { Stationary at } 1 \% \\
\text { significance level }\end{array}$ \\
\hline D.TRADE & $-4.7147 * * *$ & $\begin{array}{l}\text { Stationary at } 1 \% \\
\text { significance level }\end{array}$ \\
\hline D.lnGDPpercapita & $-3.7652 * * *$ & $\begin{array}{l}\text { Stationary at } 1 \% \\
\text { significance level }\end{array}$ \\
\hline D.lnPOPULATION & $-2.1748 * * *$ & $\begin{array}{l}\text { Stationary at } 1 \% \\
\text { significance level }\end{array}$ \\
\hline D.URBAN & $-2.5815^{* * *}$ & $\begin{array}{l}\text { Stationary at } 1 \% \\
\text { significance level }\end{array}$ \\
\hline
\end{tabular}

The symbols *,**, and *** denote the significance at the 10\%, 5\%, and 1\% levels, respectively.

It showed that these previously non-stationary variables have become stationary after taking the first-difference. Due to the reason that we have variables with the order of integration I (0) and I (1), it is necessary to consider the impact of independent variables on $\mathrm{CO} 2$ emission in the longrun as well as short-run. Furthermore, it is very important to examine whether our variables including sociological (population impact and urbanization), economic (FDI, Trade openness and GDP per capita) and energy usage factor (energy intensity and renewable energy) are cointegrated. For this purpose, we performed the panel cointegration tests and the results are represented in Table 5.

Table 5. Co-integration test by Kao (1999) and Pedroni $(1999,2004)$

\begin{tabular}{lcc}
\hline \multicolumn{1}{c}{ Types of co-integration test } & Kao (1999) & Pedroni (1999, 2004) \\
\hline Modified Phillips-Perron t & $5.0513^{* * *}$ \\
Phillips-Perron t & $-4.4530^{* * * *}$
\end{tabular}


Augmented Dickey-Fuller t

Modified Dickey-Fuller t

Dickey-Fuller $\mathrm{t}$

Unadjusted modified Dickey-Fuller t

Unadjusted Dickey-Fuller t

$$
\begin{array}{r}
-4.1598 * * * \\
-4.0080 * * * \\
-2.3443 * * * \\
-5.7835 * * * \\
-4.6514 * * *
\end{array}
$$

The symbols $*$, **, and $* * *$ denote the significance at the $10 \%, 5 \%$, and $1 \%$ levels, respectively. Null hypothesis is that there is no cointegration between variables.

The majority of tests employing Kao (1999) and Pedroni $(1999,2004)$ approach indicated the rejection of the null hypothesis of no cointegration implying the presence of co-integration. This finding is of high significance and provides strong evidence that the variables have a long-run relationship. Thereafter, before we employ Panel VAR (Panel Vector Autoregressive) for further examination of the relationship between $\mathrm{CO}_{2}$ emission and its determinants in Europe, we investigate the correlation between our variables. The main reason is to avoid the changing signs of coefficients under multicollinearity phenomenon.

Table 6. Correlation \& Multicollinearity Analysis

\begin{tabular}{ccccccccc}
\hline & InCO2 & FDI & ENERGY & RENEWABLE & InGDP & TRADE & URBAN & InPOP \\
\hline CO2 & 1 & & & & & & & \\
FDI & 0.0783 & 1 & & & & & & \\
ENERGY & 0.1137 & -0.1142 & 1 & & & & & \\
RENEWABLE & -0.4403 & -0.1451 & -0.0177 & 1 & & & & \\
GDP & 0.4081 & 0.0976 & -0.6701 & 0.0472 & 1 & & & \\
TRADE & 0.3244 & 0.3753 & -0.1095 & -0.2341 & 0.2157 & 1 & & \\
URBAN & 0.3865 & 0.2167 & -0.118 & -0.1881 & 0.4753 & 0.2871 & 1 & \\
POP & -0.1101 & -0.2515 & -0.0863 & -0.0799 & 0.0726 & -0.7086 & -0.0586 & 1 \\
\hline
\end{tabular}

Pearson correlation coefficients.

Based on the correlation matrix, we can observe that seemingly there is major issue of multicollinearity as no coefficients exceeds canonical rules of thumb (i.e. 0.70 or 0.80 etc). There are only two pairs which exceed the 0.6 i.e. Energy intensity and GDP per capita, -0.67 as well as Trade and Population, - 0.70 . To gain further insight and robustness, we performed the Variance Inflation Factors (VIFs) test to examine any potential multicolinearity. The results are presented in Table 7.

Table 7. Variance Inflation Factor Test

\begin{tabular}{lc}
\multicolumn{1}{c}{ Variables } & VIF \\
\hline TRADE & 3.16 \\
GDP & 2.88 \\
POPULATION & 2.72 \\
ENERGY & 2.06 \\
URBAN & 1.6
\end{tabular}




\begin{tabular}{ll} 
RENEWABLE & 1.35 \\
FDI & 1.21 \\
\hline
\end{tabular}

As shown in Table 7, all our variables have VIF values below the 3.3 which is the benchmark suggested by Kock $(2015)^{8}$. Therefore, we can conclude that our results do not have the issue of multicollinearity. This gives us reason to proceed and take a closer look at determinants of $\mathrm{CO}_{2}$ emissions in 28 European countries.

\subsection{Panel VAR, GMM and FMOLS Estimations}

The estimation strategy entails Panel VAR application with the use of GMM-style instruments for the short-run evaluation and FMOLS estimations for long-run co-integration. It showed that most of the variables are statistically significant. There is strong evidence that if $\mathrm{CO}_{2}$ increases one metric tonne per capita in a year, the next year the amount of $\mathrm{CO}_{2}$ will have the snowballing effect. Regarding the population, there is weak evidence (as significance at 5\% level) that population growth in a year will have a positive impact on the environmental degradation index of the following year. However, considering the long-run period, population growth correlates positively with the carbon emission amount at a significance level of $1 \%$. This finding complements the results by Yeh and Liao (2017) on Taiwan, Liddle (2013) study on selected developed and developing countries, and study by Bargaoui et al (2014) which employed cross-sectional analysis. Therefore, it fits the Malthusian notion that population growth is a crucial factor contributing to ecological deterioration since the Earth's capacity is being constrained gradually while population size is continuously expanding. Although urbanization seems to have a negative effect on $\mathrm{CO}_{2}$ emission in the short-run, it corresponds positively with the increasing amount of carbon emissions in the long-run. It means that urbanization perhaps improves the quality of the environment in the short-term period while this factor causes environmental degradation in the long run. The result is very important since there are many studies has argued that urbanisation is the stimulant for population growth which comes at an ecological cost (Yeh and Liao 2017; Poumanyvong and Kaneko 2010; O’Neill, et al. 2012; Bargaoui et al 2014; and Martinez-Zarzoso and Maruotti 2011).

Table 8. Panel VAR estimation with the use of GMM-style instruments

\begin{tabular}{|c|c|}
\hline Variables & Coefficients \\
\hline $\operatorname{lnCO} 2_{(t-1)}$ & $\begin{array}{c}0.8334 * * * \\
{[6.67]}\end{array}$ \\
\hline $\mathrm{FDI}_{(\mathrm{t}-1)}$ & $\begin{array}{c}-0.0001 * * * * \\
{[-1.18]}\end{array}$ \\
\hline $\operatorname{ENERGY}_{(\mathrm{t}-1)}$ & $\begin{array}{c}-0.0226 * * * * \\
{[-3.33]}\end{array}$ \\
\hline $\operatorname{RENEWABLE}_{(\mathrm{t}-1)}$ & $\begin{array}{c}-0.9315 * * * \\
{[-3.12]}\end{array}$ \\
\hline $\operatorname{TRADE}_{(\mathrm{t}-1)}$ & $\begin{array}{c}-0.1192 * * * * \\
{[-3.01]}\end{array}$ \\
\hline $\operatorname{lnGDPPERCAPITA}_{(\mathrm{t}-1)}$ & $\begin{array}{l}0.0171 \\
{[0.89]}\end{array}$ \\
\hline $\operatorname{lnPOPULATION}_{(\mathrm{t}-1)}$ & $\begin{array}{c}0.2922^{* *} \\
{[2.11]}\end{array}$ \\
\hline
\end{tabular}

\footnotetext{
${ }^{8}$ Note: some studies have even suggested even more linear benchmark of 10.
} 


$$
\begin{aligned}
& \operatorname{URBAN}_{(\mathrm{t}-1)} \\
& -0.7014 * * * \\
& {[-3.18]}
\end{aligned}
$$

\begin{tabular}{|c|c|c|}
\hline Variables & Coefficients & EKC Coefficients \\
\hline \multirow{2}{*}{ FDI } & $0.001 * * *$ & $0.001 * * *$ \\
\hline & {$[17.38]$} & {$[25.91]$} \\
\hline \multirow{2}{*}{ ENERGY } & $0.13 * * *$ & $0.12 * * *$ \\
\hline & {$[122.01]$} & {$[149.64]$} \\
\hline \multirow{2}{*}{ RENEWABLE } & $-2.32 * * *$ & $-2.10 * * *$ \\
\hline & {$[-86.17]$} & {$[-102.65]$} \\
\hline \multirow{2}{*}{ TRADE } & $0.26 * * *$ & $0.22 * * *$ \\
\hline & {$[65.25]$} & [69.18] \\
\hline \multirow{2}{*}{ InGDPPERCAPITA } & 0.12 & $0.48 * * *$ \\
\hline & [48.33] & {$[13.03]$} \\
\hline lnGDPPERCAPITA ${ }^{2}$ & & $\begin{array}{c}-0.02 * * * \\
{[-9.17]}\end{array}$ \\
\hline \multirow{2}{*}{ InPOPULATION } & $0.30 * * *$ & $0.08 * * *$ \\
\hline & [8.14] & [7.38] \\
\hline \multirow{2}{*}{ URBAN } & $0.33 * *$ & $0.63 * *$ \\
\hline & [2.22] & [2.83] \\
\hline
\end{tabular}

Table 9. FMOLS estimations for long-run co-integration

Looking at the affluence factor, similar to the urbanisation, economic growth (proxied by GDP per capita) also raises the amount of $\mathrm{CO}_{2}$ in the long-run at a significance level of $1 \%$. This outcome supports the findings of previous studies (Yeh and Liao 2017; Liddle 2013; Poumanyvong and Kaneko 2010; O'Neill, et al. 2012; and Bargaoui et al 2014). It can be inferred that affluence shares a large responsibility in consuming resources and lead to entropy through increasing carbon dioxide emissions (Rifkin 2011: 23; Ghisellini et al 2016; Boehnert 2018). Although FDI tends to emit less carbon for the following year, nonetheless, with the long-run estimation, it still bequeaths environmental degradation. Despite the fact that the European countries are keen to channel FDI to projects with sustainability aspect, many foreign investors are still fond of fossil fuel-intensive and energy-intensive sectors, such as oil refinery, pharmaceuticals, electronics and electrical equipment, and even mining (see European Commission 2019). Similar to FDI, Trade has a significant effect on $\mathrm{CO}_{2}$ emission, negative in the short-run yet positive in the long-run. Since with the globalisation many companies from the developed countries, including western European nations, tried to relocate production in developing countries to utilise cheap labour, that trade in Europe does not contribute much effect on the carbon emission of this region. However, since these nations need to import back the refined and final products it leads to $\mathrm{CO}_{2}$ (Lee, 2013; Omri et al., 2014). It also implies that the European policymakers are to be aware of "pollution haven" traps, which does not encourage foreign direct investment at any cost. It cannot be emphasised enough that authorities should pay attention to the "environmental quality" by considering the long-run implications of FDI as well as Trade and trade deals.

The third explanatory factor which we expected to have a negative effect on the environmental degradation ( $\mathrm{CO}_{2}$ emissions) turned out not to be as expected, yet it is appeared to have a partial grip of it. Thanks to the technological development and the green transition that 
renewable energy is mitigating the pressure of population and affluence on environmental deterioration. It showed that an increase in renewable energy consumption will decrease the amount of $\mathrm{CO}_{2}$ per capita at the statistical significance level of $1 \%$. Though the renewable energy variable has a crucial impact on carbon emission mitigation, both in the short-run and long-run at a significant level of $1 \%$, the energy intensity showed a mixed result between two-time ranges. Since this variable stands for the amount of energy needed to produce a unit of output that in the shortrun, due to technological advancement and the expanding shares of renewable resources in the energy mix of EU nations that even the higher the energy intensity, the lower the negative effect it produces to the environment. Nevertheless, as postulated by the theory of rebound effect, in the long-run estimation, the consumers tend to consume more since they can save more from the result of energy intensity (Bhattacharyya 2011: Zink and Geyer 2017; Korhonen et al 2018). That leads to the fact that in the long-run, this variable still correlates positively with $\mathrm{CO}_{2}$ emission. Particularly, an increase in energy intensity by $1 \%$ causes the increase in carbon emission per capita by $0.82 \%$. It is surprising that the rebound effect in the EU zone seems to possess heavier magnitude than other variables. Lastly, although the prime focus of this study was not the EKC model, we still employed it for robustness and to see whether the results between the two models are different. The outcome (Table 9) is very affirmative as the effects of the explanatory factors in STIRPAT turn out to be the same as the coefficients of EKC. Moreover, in the EKC, there is significant evidence to support the quadratic term of GDP - GDP ${ }^{2}$. This is also in-line with the study of Dogan and Seker (2016), Lapinskiene et al. (2015) regarding the existence of EKC in European countries. Thus, it can be argued that not only our results are robust, but the EKC model does provide "the point of return" of GDP regarding its effect on environmental degradation. There is logically point where despite continuously increase in GDP, income-satiated countries will seek to curb the emissions.

\section{Conclusion and Implications}

Our results lead us to conclude that in Europe population size, urbanization, economic growth, FDI, trade, and energy intensity all correlates positively with the carbon emission though in different magnitudes. The only renewable energy consumption has a negative effect on the environmental degradation measured by carbon emissions. The employed STIRPAT framework suggests that we need to revisit our approach to population and affluence factor in Europe. If the Europeans are serious to tackle climate issues, they need to embed their population and economic growth policies with the ecological concerns. Indeed, the technological advancement can play a role, however, it is not a panacea. Our findings have profound implication for the European countries and their comments to tackle climate change and honour the Paris Agreement (COP:21) as well as achieving the key targets set including the 2030 climate \& energy framework.

Regarding the population growth, the trend over the last decade suggests that population size and urbanisation tend to increase in Europe. The population size of the EU is projected to increase slowly but steadily till the $4^{\text {th }}$ decade of this century, thereafter it will meet the peak point and decrease gradually (Eurostat 2019). Urbanization in the EU was approximately $75 \%$ in 2015 and it is predicted to increase only 5\% more by 2050 (Eurostat 2016). Therefore, it is intuitive to argue that the although population and urbanisation may increase the emissions in the EU, considering very marginal increase in them does not account them as a major factor for increasing emissions rates. Therefore, strict population control may not be required in the policy setting. However, net immigration in the EU has been showing some changes in the last decade, especially the migration crisis in 2015 (European Commission 2017). Thus, the population growth of EU in 
the future can be affected from migration to some extent, however, considering the fact that the ratio to net migration to total population is very small and emissions is a global phenomenon it does not make much difference. In fact, EU policymakers should shift much of their focus on affluence and technology factors and facilitating the indigenous Europeans and migrant population to participate in efforts to tackle climate change.

Among the variables accounting for the factor of affluence, trade is seen to have a positive association with the emissions. From the First Industrial Revolution until now, specialization has been one of the crucial points in global business. Globalisation based on the notion of specialization which does not only decrease the unit cost of production but also create the foundation for integrating technological enhancement to improve the efficiency of the work (Rifkin 1995). From David Ricardo's idea of comparative advantage to contemporary neo-classical theory of international economics, specialisation has been proved to be efficient (Fischer, et al. 2018) as well as the efficiency of economies of scale (Evans and Hunt 2009). Yet, this efficiency through specialisation and global division of work has been rarely seen through the ecological lens. Trade activities and cargo shipments based on fossil fuel have been leading to an ecologically less efficient outcome. This implies that ecological trade, as well as the de-urbanization, shall be brought as one of the vital methods to avoid carbon emission from export and import activities. The projects like mini-farming, locally made products, and localisation can be helpful in enhancing the domestic values and escaping from the emission of trading activities (Satterthwaite et al 2010; Stodder, 2009). In this regard, de-centralization of energy and electricity can also be an effective tool. In fact, some studies have proved that with communities that can provide energy independently from the national grid is better than a perspective of building a regional renewable power plant because huge plants tend to have much energy lost from transmission (UCSUSA 2017), and regions have different features to support variances of renewable energy resources (Goldthau 2014). Although this trend is new, it will take much time and effort for the whole EU to apply it as the framework and into legislations, since there are considerable obstacles from the businesses and political circles (Geels, 2014). The economic growth which has been the focal point of the debate on climate change also showed to have an increasing impact on the emissions in European countries. Last but not least, as our results lead us to conclude on the presence of rebound effects of energy intensity which was, in fact, the variable with the largest negative effect on the environment. The occurrence of the rebound effect is mostly due to the proportionate change in energy use and the energy demand i.e. the elasticity of energy demand due to energy efficiency. Therefore, the efforts to decrease energy intensity can backfire due to extremely high elasticity (Evans and Hunt 2009). Therefore, the goal of decreasing energy intensity may not help EU much in her efforts to tackle climate issues. Perhaps, a policy of segregating the sectors based on the energy intensity and sectoral level climate policy might be the right approach to benefit from increased energy efficiency and controlling rebound effect.

The subject study has been focused on the European countries, however, the underlying analytical framework and inquiry can be extended to other countries, including the developing economies and regions, as some of them are also facing high population growth and increasing affluence. The recent expeditious economic progress in historically less affluent parts of the world is adding to the global environmental challenges which can only be tackled through a global consensus such as the Paris Agreement. There is no doubt that as the citizens of the world, we are together in it! 


\section{References}

Ausubel, H. J. \& Langford, D. H. (1997). Technological Trajectories and the Human Environment. Washington, D. C.: National Academy Press.

Bargaoui, A. S., Liouane, N. Nouri, Z. F. (2014). Environmental Impact determinants: An empirical analysis based on the STIRPAT model. Procedia - Social and Behavioral Sciences, 109, $449-458$.

Bhattacharyya, C. S. (2011). Energy Economics. Concepts, Issues, Markets and Governance. UK: Springer.

Blaikie, N. \& Priest, J. (2019). Designing Social Research (3rd edition). Cambridge: Polity Press.

Boehnert, J. (2018). Anthropocene Economics and Design: Heterodox Economics for Design Transitions. She Ji: The Journal of Design, Economics, and Innovation, 4(4), 355 - 374.

Bucci, A., Eraydin, L. \& Muller, M. (2018). Dilution effects, population growth and economic growth under human capital accumulation and endogenous technological change. Journal of Macroeconomics. Advance online publication. DOI: https://doi.org/10.1016/j.jmacro.2018.08.003

Cai, F. (2010). Demographic transition, demographic dividend, and Lewis turning point in China. China Economic Journal, 3(2), 107 - 119.

Chang, Y., Fang, Z., Hamori, S. \& Chow, D. (2018). A Sustainable Metropolis: Perspectives of Population, Productivity and Parity. Sustainability, 10(11), 4264.

Chertow, R. M. (2001). The IPAT Equation and Its Variants. Changing Views of Technology and Environmental Impact. Journal of Industrial Ecology, 4(4), 13 - 29.

Cole, A. M. \& Neumayor, E. (2004). Examining the Impact of Demographic Factors on Air Pollution. Population and Environment, 26, 5 - 21.

Daily History. (2019). How did the Bubonic Plague make the Italian Renaissance possible?

Retrieved from: https://dailyhistory.org/How_did_the_Bubonic_Plague_make the_Italian _Renaissance_possible\%3F\#cite_note-8

Daily, C. G. \& Erhlich, R. P. (1992). Population, Sustainability, and Earth's Carrying Capacity. Bioscience, 42(10), $761-771$.

Dietz, T. Rosa, A. G. (1997). Effects of population and affluence on CO2 emissions. Proceedings of the National Academy of Sciences of the United States of America, 94(1), 175 179.

Dogan, E., \& Seker, F. (2016). Determinants of CO2 emissions in the European Union: The role of renewable and non-renewable energy. Renewable Energy, 94, 429-439.

Dong, K., Hochman, G., Zhang, Y., Sun, R., Li, H. \& Liao, H. (2018). CO2 emissions, economic and population growth, and renewable energy: Empirical evidence across regions. Energy Economics, 75, 180 - 192.

Ehrlich, R. P. (1968). The Population Bomb. U.S.A.: Ballantine Books, Inc.

Ehrlich, R. P. \& Holdren, P. J. (1971). Impact of Population Growth. Science, 171(3977), $1212-1217$.

European Commission. (2015). EU ETS Handbook. Retrieved from: https://ec.europa.eu/clima/policies/ets_en

European Commission. (2017). The EU and the migration crisis. Retrieved from: http://publications.europa.eu/webpub/com/factsheets/migration-crisis/en/

European Commission. (2019). Foreign direct investment report: continuous rise of foreign ownership of European companies in key sectors. Retrieved from: http://trade.ec.europa.eu/doclib/press/index.cfm?id=1993 
European Commission. (2019). Circular Economy. Implementation of the Circular Economy Action Plan. Retrieved from: https://ec.europa.eu/environment/circulareconomy/index_en.htm

Eurostat. (2016). Urban Europe. Statistics on Cities, Towns, and Suburbs. Luxembourg: Publications office of the European Union. Retrieved from: https://ec.europa.eu/eurostat/en/web/products-statistical-books/-/KS-01-16-691

Eurostat. (2019). Visualisation: Population Development \& Projections. Retrieved from: https://ec.europa.eu/eurostat/web/population-demography-migration-projections/visualisations

Evans, J. \& Hunt, C. L. (2009). International Handbook on the Economics of Energy. UK \& USA: Edward Elgar Publishing Limited.

Fischer, L., Hasell, J., Procter, C. J., Uwakwe, D., Ward-Perkins, Z. \&Watson, C. (2018). Rethinking Economics. An Introduction to Pluralist Economics. London and New York: Routledge.

Geels, W. F. (2014). Regime Resistance against Low-Carbon Transitions: Introducing Politics and Power into the Multi-Level Perspective. Theory, Culture \& Society, 31(5), 21 - 40.

Ghisellini, P., Cialani, C. \& Ulgiati, S. (2016). A review on circular economy: the expected transition to a balanced interplay of environmental and economic systems. Journal of Cleaner Production 114, $11-32$.

Golley, J. \& Wei, Z. (2015). Population dynamics and economic growth in China. China Economic Review, 35, $15-32$.

Goldthau, A. (2014). Rethinking the governance of energy infrastructure: Scale, decentralization and polycentrism. Energy Research \& Social Science, 1, 134- 140.

Grether, J.M., Mathys, N.A. de Melo, J. Scale, Technique and Composition Effects in Manufacturing SO2 Emissions, Environmental and Resource Economics 43: 257-274.

Grossman, M. G. \& Krueger, B. A. (1991). Environmental Impacts of A North American Free Trade Agreement. (No. w3914). National Bureau of Economic Research. DOI: https://www.nber.org/papers/w3914

Hanif, I. \& Gago-de-Santos, P. (2017). The importance of population control and macroeconomic stability to reducing environmental degradation: An empirical test of the environmental Kuznets curve for developing countries. Environmental Development, 23, 1 - 9 .

Hardin, G. (1968). The Tragedy of the Commons. Science, 162(3859), $1243-1248$.

Daily C. G. \& Ehrlich, R. P. (1992). Population, Sustainability, and Earth's Carrying Capacity. Bioscience, 42(10), $761-771$.

Hill, C. R., Griffiths, E. W. \& Lim, C. G. (2011). Principles of Econometrics. (4th ed). USA: john Wiley \& Sons.

Hille, E. Shahbaz, M. (2019). "Sources of emission reductions: Market and policystringency effects," Energy Economics, 78(C): 29-43.

Holtz-Eakin, D., Newey, W., \& Rosen, H. S. (1988). Estimating vector autoregressions with panel data. Econometrica: Journal of the Econometric Society, 1371-1395.

IMBd. (2019). Inferno (2016). Retrieved from: https://www.imdb.com/title/tt3062096/

International Energy Agency. (2017). World Energy Outlook 2017. Paris: Organisation for Economic Co-operation and Development.

International Energy Agency. (2018). World Energy Outlook 2018. Paris: Organisation for Economic Co-operation and Development.

Jonsson, A. F. (2014). The Origins of Cornucopianism: A Preliminary Genealogy. Critical History Studies, 1(1), $1-18$. 
Jorgenson, K. A. \& Clark, B. (2010). Assessing the temporal stability of the population/ environment relationship in comparative perspective: a cross-national panel study of carbon dioxide emissions, 1960-2005. Population and Environment, 32, 27 - 41.

Kalmykovaa, Y., Sadagopanb, M. \& Rosadoc, L. (2018). Circular economy - From review of theories and practices to development of implementation tools. Resources, Conservation \& Recycling 135, 190 - 201.

Kiel, K., Matheson, V. \& Golembiewshi, K. (2010). Luck or skill? An examination of the Ehrlich-Simon bet. Ecological Economics, 69, 1365 - 1567.

Kirchherr, J., Reike, D. \& Hekkert, M. (2017). Conceptualizing the circular economy: An analysis of 114 definitions. Resources, Conservation \& Recycling, 127, $221-232$.

Kock, N. (2015). Common method bias in PLS-SEM: A full collinearity assessment approach. International Journal of e-Collaboration (IJeC), 11(4), 1-10.

Kolbert, E. (2014). The Sixth Extinction: An Unnatural History. New York: Henry Holt and Co.,

Korhonen, J., Honkasalo, A. \& Seppälä, J. (2018). Circular Economy: The Concept and its Limitations. Ecological Economics, 143, 37-46

Kuznets, S. (1955). Economic Growth And Income Inequality. The American Economic Review, 45(1), 1 - 28.

Lapinskienè, G., Peleckis, K., \& Radavičius, M. (2015). Economic development and greenhouse gas emissions in the European Union countries. Journal of Business Economics and Management, 16(6), 1109-1123.

Lee, J. W. (2013). The contribution of foreign direct investment to clean energy use, carbon emissions and economic growth. Energy Policy, 55, 483-489.

Liddle, B. (2011). Consumption-driven environmental impact and age structure change $749-770$.

in OECD countries: A cointegration-STIRPAT analysis. Demographic Research, 24(30),

Liddle, B. (2013). Population, affluence, and environmental impact across development: Evidence from panel cointegration modeling. Environmental Modelling \& Software, 40, 255 - 266.

Liddle, B. (2015). What are the carbon emissions elasticities for income and population? Bridging STIRPAT and EKC via robust heterogeneous panel estimates. Global Environmental Change, 31, $62-73$.

Liddle, B. \& Lung, S. (2010). Age-structure, urbanization, and climate change in developed countries: revisiting STIRPAT for disaggregated population and consumption-related environmental impacts. Population And Environment, 31, 317 - 343.

Liu, S. \& Hu, A. (2013). Demographic change and economic growth: Theory and evidence from China. Economic Modelling, 35, 71 - 77.

Lloyds, W.F. (1833), Two lectures on the checks to population, The University of Oxford, available at https://archive.org/details/twolecturesonch00lloygoog/page/n1

Malthus, T. (1798). An Essay on The Principle of Population. London: Electronic Scholarly Publishing Project. Retrieved from: http://www.esp.org/books/malthus/population/malthus.pdf

Markets Insider. (2019). CO2 European Emission Allowances. Retrieved from: https://markets.businessinsider.com/commodities/co2-european-emission-allowances

Marsiglio, S. (2011). On the relationship between population change and sustainable development. Research in Economics, 65, 353 - 364.

Martinez-Zarzoso, I., Bengochea-Morancho, A. \& Morales-Lage, R. (2007). The impact of population on $\mathrm{CO} 2$ emissions: evidence from European countries. Environmental and Resource Economics, 38(4), $497-512$. 
Martinez-Zarzoso, I. \& Maruotti, A. (2011). The impact of urbanization on CO2 emissions: Evidence from developing countries. Ecological Economics, 70, 1344 - 1353.

McCormick, J. (2018). Environmental Politics and Policy. London: Palgrave.

McDonough, W. \& Braungart, M. (2002). Cradle-to-Cradle: remaking the way we make things. Canada: Doughlas \& McIntyre Ltd.

Meadows, H. D., Meadows, D. L., Randers, J. \& Behrens, W. W. III. (1972). The Limits to Growth. Washington DC: Patomac Associates.

Menz, T. \& Welsch, H. (2012). Population aging and carbon emissions in OECD countries: Accounting for life-cycle and cohort effects. Energy Economics, 34, 842 - 849.

Nasir, M. A. Huynh, T.L. D. Tram, H.T.X. (2019), Role of financial development, economic growth \& foreign direct investment in driving climate change: A case of emerging ASEAN, Journal of Environmental Management, 242, 131-141.

Neuman, L. W. (2014). Social Research Methods: Qualitative And Quantitative Approaches (7th edition). Essex: Pearson Education Limited.

Odum, T. H \& Odum, C. E. (2001). A Prosperous Way Down. U.S.A.: The University Press of Colorado.

Odum, T. H \& Odum, C. E. (2006). The prosperous way down. Energy, 31, 21 - 32.

O’Niell, B. C., Liddle, B., Jiand, L., Smith, K. R., Pachauri. S., Dalton, M. \& Fuchs, R. (2012). Demographic change and carbon dioxide emissions. The Lancet, 380(9387), 157 - 164.

Omri, A., Nguyen, D. K., \& Rault, C. (2014). Causal interactions between CO2 emissions, FDI, and economic growth: Evidence from dynamic simultaneous-equation models. Economic Modelling, 42, 382-389.

Özokcu, S., Özdemir, Ö., 2017. Economic growth, energy, and environmental Kuznets curve. Renewable \& Sustainable Energy Reviews 72, 639-647.

Pedroni, P. (2001). Fully modified OLS for heterogeneous cointegrated panels. In Nonstationary panels, panel cointegration, and dynamic panels (pp. 93-130). Emerald Group Publishing Limited.

Per Square Mile. (2012). If the world's population lived like, Retrived from: https://persquaremile.com/2012/08/08/if-the-worlds-population-lived-like/

Peterson, W. F. E. (2017). The Role of Population in Economic Growth. SAGE Open, 7(4), $1-15$.

Pimm, L. S., Jenkins, N. C., Abell, R., Brooks, M. T., Gittleman, L. J., Joppa, N. L., Raven, H. P., Roberts, M. C. \& Sexton, O. J. (2014). The biodiversity of species and their rates of extinction, distribution, and protection. Science, 344(6187), $1-10$.

Population Reference Bureau. (2019). World Population 7 Billion. Retreived from: https://www.prb.org/world-population-7billion/

Poumanyvong, P. \& Kaneko, S. (2010). Does urbanization lead to less energy use and lower CO2 emissions? A cross-country analysis. Ecological Economics, 70, 434 - 444.

Raworth, K. (2017). Doughnut Economics. London: Random House Business Books.

Rifkin, J. (1995). The End Of Work. The Decline of the Global Labor Fource and the Dawn of the Post-Market Era. New York: G. P. Putnam's Sons.

Rifkin, J. (2011). The Third Industrial Revolution: How Lateral Power is Transforming Energy, the Economy, and the World. New York: Palgrave Macmillan.

Rodriguez-Gonzalez, T. P, Rico-Martinez, R.. \& Rico-Ramirez, V. (2018). An integrated stochastic economic-ecological-social model with stratified-population. Ecological Modelling, $368,15-26$.

Satterthwaite, D., McGranahan, G. \& Tacoli, C. (2010). Urbanization and its implications for food and farming. Philosophical Transactions of The Royal Society B, 365, 2809 - 2820. 
Shi, A. (2003). The impact of population pressure on global carbon dioxide emissions, 1975 - 1996: evidence from pooled cross-country data. Ecological Economics, 44, 29 - 42.

Siche, R. J., Agostinho, F., Ortega, E. \& Romeiro, A. (2008). Sustainability of nations by indices: Comparative study between environmental sustainability index, ecological footprint and the emergy performance indices. Ecological Economics, 66, 628 - 637.

Sinn, H. W. (2012). The Green Paradox. A Supply-side Approach to Global Warming. London: MIT Press.

Stodder, J. (2009). Complementary credit networks and macroeconomic stability: Switzerland's Wirtschaftsring. Journal of Economic Behavior \& Organization, 72, 79-95.

Taylor, G. (2019). Prime Minister urges Norwegians to make babies. Retrieved from: https://norwaytoday.info/news/prime-minister-worried-about-low-birth-rates-asks-norwegians-tomake-more-babies/

Tinbergen, J. (2005). Econometrics. Oxon: Routledge.

Tsurumi, T., and Managi, S. (2010). Decomposition of the environmental Kuznets curve: Scale, technique, and composition effects. Environmental Economics and Policy Studies, 11(1-4), 19-36

United Nations. (2015). Paris Agreement. Retrieved from URL: https://unfccc.int/processand- meetings/the-paris-agreement/the-paris-agreement/

United Nations. (2015). Transforming Our World: the 2030 Agenda for Sustainable Development. Retrived from URL: https://www.un.org/sustainabledevelopment/developmentagenda/

UCSUSA. (2017). Barriers to Renewable Energy Technologies. Retrieved from: https://www.ucsusa.org/clean-energy/renewable-energy/barriers-to-renewable-energy

Van Der Ploeg, F. \& Withagen, C. (2015). Global Warming and the Green Paradox: A Review of Adverse Effects of Climate Policies. Review of Environmental Economics and Policy, $9(2), 285-303$.

Wang, X. S., Fu, B. Y. \& Zhang, G. Z. (2015). Population growth and the environmental Kuznets curve. China Economic Review, 36, 146 - 165.

Wei, T. (2011). What STIRPAT tells about effects of population and affluence on the environment? Ecological Economics, 72, 70 - 74.

Westcott, B. (2018). China moves to end two-child limit, finishing decades of family planning. Retrieved from: https://edition.cnn.com/2018/08/28/asia/china-family-planning-onechild-intl/index.html

Worldometers. (2019). Current World Population. Retrieved from URL: http://www.worldometers.info/world-population/

Wongboonsin, K. \& Phiromswad, P. (2017). Searching for empirical linkages between demographic structure and economic growth. Economic Modelling, 60, 364 - 379.

Yeh, J. \& Liao, C. (2017). Impact of population and economic growth on carbon emissions in Taiwan using an analytic tool STIRPAT. Sustainable Environment Research, 27, 41 - 48.

York, R., Rosa, A. E. \& Dietz, T. (2002). Bridging Environmental Science with Environmental Policy: Plasticity of Population, Affluence, and Technology. Social Science Quarterly, 83(1), 18 - 34.

York, R., Rosa, A. E. \& Dietz, T. (2003). STIRPAT, IPAT and ImPACT: analytic tools for unpacking the driving forces of environmental impacts. Ecological Economics, 46, 351 - 365.

Zhang, Z., Hao, Y., Lu, Z. \& Deng, Y. (2018). How does demographic structure affect environmental quality? Empirical T evidence from China. Resources, Conservation \& Recycling, $133,242-249$. 
Zink, T. \& Geyer, R. (2017). Circular Economy Rebound. Journal of Industrial Ecology, 21(3), 593-602. 